\title{
Analisis Pengaruh Gaya Kepemimpinan dan Motivasi Terhadap Kinerja Karyawan PT. Kimia Farma, Tbk.
}

\author{
M. Ardi Nupi Hasyim \\ Institut Manajemen Koperasi Indonesia \\ ard.nupi@gmail.com \\ Muhamad Azhari Kartiwa \\ Institut Manajemen Koperasi Indonesia \\ azharimkartiwa@gmail.com
}

Riana Kusumawati

Institut Manajemen Koperasi Indonesia rianaksmwt@gmail.com

\section{Siska Nuraini}

Institut Manajemen Koperasi Indonesia siskanurainicans12@gmail.com

Abstrak
Perusahaan saat ini menghadapi lebih banyak tantangan dalam kondisi
ekonomi, sosial hingga politik yang berubah dengan cepat. Kita dituntut
untuk dapat berinovasi da peka terhadap setiap peluang dan kesempatan
yang ada. Untuk mengatasi kondisi tersebut, dunia usaha saat ini harus
mampu menciptakan karyawan yang berkinerja tinggi untuk
perkembangan perusahaan. Hal tersebut tidak lepas dari Sumber Daya
Manusia (SDM) sebagai faktor utama, karena Sumber Daya Manusia
merupakan komponen penting sebagai penggerak kegiatan produksi
perusahaan. Penelitian ini bertujuan untuk mengetahui: 1) Mengetahui
pemberian motivasi kerja terhadap kinerja karyawan Bagian Granulasi 1
PT. Kimia Farma, Tbk. Plant Banjaran. 2) Mengetahui disiplin kerja
terhadap kinerja karyawan Bagian Granulasi 1 PT. Kimia Farma, Tbk.
Plant Banjaran. 3) Mengetahui pengaruh pemberian motivasi dan disiplin
kerja terhadap kinerja karyawan Bagian Granulasi 1 PT. Kimia Farma,
Tbk. Plant Banjaran. Objek populasi penelitian ini adalah PT. Kimia
Farma Tbk. Plant Banjaran. Jenis penelitian yang dilakukan adalah
puposive sampling yaitu Bagian Produksi Granulasi 1 PT. Kimia Farma
Tbk. Plant Banjaran dan menggunakan pendekatan kualitiatif. Teknik
pengumpulan data yang digunakan adalah wawancara. Berdasarkan hasil
penelitian menunjukan keberhasilan Bagian Produksi Granulasi 1 PT.
Kimia Farma, Tbk. dalam mencapai target produksi sangat bergantung
pada kualitas kinerja karyawan yang baik, maka dari itu peningkatan
motivasi dan kedisiplinan sangat diperhatikan oleh organisasi.
Gaya Kepemimpinan, Motivasi Kerja, Disiplin Kerja dan Kinerja
karyawan

\section{PENDAHULUAN}

Perusahaan adalah segala bentuk bisnis yang permanen dan berkelanjutan dan yang didirikan, berkerja dan berdomisili di wilayah Republik Indonesia dengan tujuan 
memperoleh keuntungan dan atau manfaat (UU No. 3 tahun 1982). Perusahaan saat ini menghadapi lebih banyak tantangan dalam kondisi ekonomi, sosial hingga politik yang berubah dengan cepat. Untuk mengatasi kondisi tersebut, dunia usaha saat ini harus mampu menciptakan karyawan yang berkinerja tinggi untuk perkembangan perusahaan. Hal tersebut tidak lepas dari Sumber Daya Manusia (SDM) sebagai faktor utama, karena Sumber Daya Manusia merupakan komponen penting sebagai penggerak kegiatan produksi perusahaan.

Dalam menjalankan kegiatan perusahaan, manajemen perusahaan menyadari bahwa peran SDM sangat penting, dan pengelolaan SDM tidak terlepas dari faktor-faktor pegawai yang mengharapkan kinerja terbaik untuk mencapai tujuan perusahaan. Proses kebijakan pengelolaan SDM tidak lepas dari pengaruh yang ada di sekitarnya, baik lingkungan organisasi maupun lingkungan eksternal akan berdampak pada manajemen. Faktor-faktor tersebut terbagi menjadi dua jenis yaitu faktor internal dan faktor eksternal. Faktor internal merupakan faktor yang berhubungan dengan karakter seseorang yaitu disiplin kerja, motivasi kerja, dll. Sedangakan faktor eksternal merupakan faktor dari lingkungan kerja yang mempengaruhi kinerja manusia.

PT. Kimia Farma. Tbk. Adalah salah satu Badan Usaha Milik Negara yang bergerak dibidang jasa, memproduksi farmasi dan jasa pelayanan kesehatan yang berkualitas tinggi dengan menunjukkan kemajuan pesat dan peningkatan bisnis dalam industri farmasi terintegritas dengan mendapatkan dukungan sumber daya manusia yang profesional. PT. Kimia Farma Tbk. Plant Banjaran adalah salah satu unit produksi PT. Kimia Farma yang ada di Banjaran. Plant Banjaran mengkhususkan pada produksi tablet dan kaplet. Dalam hal ini peneliti akan meneliti kinerja pegawai PT. Kimia Farma Plant Banjaran khususnya ada bagian granulasi produksi 1 .

Granulasi Produksi 1 merupakan proses awal dalam memproduksi suatu obat tablet pencampuran antara zat aktif dalam bahan tablet tersebut dengan zat tambahan yang ada disetiap komponen yang terdapat beberapa rangka sehingga menjadikan sebuah tablet. Berdasarkan latar belakang tersebut, penulis tertarik untuk melakukan penelitian dengan judul "Analisi Pengaruh Gaya Kepemimpinan dan Motivasi Terhadap Kinerja Karyawan PT. Kimia Farma, Tbk."

\section{Rumusan Masalah}

Bagaimana pengaruh gaya kepemimpinan dalam pemberian motivasi dan disiplin kerja terhadap kinerja karyawan (Studi Kasus Pada Bagian Produksi Granulasi 1 PT. Kimia Farma, Tbk.)

\section{Tujuan Penelitian}

Berdasarkan permasalahan yang sudah dirumuskan dalam rumusan masalah, maka tujuan penelitian ini adalah mengetahui pemberian motivasi kerja, disiplin kerja serta pengaruh pemberian motivasi dan disiplin kerja terhadap kinerja karyawan Bagian Granulasi 1 PT. Kimia Farma, Tbk. Plant Banjaran.

\section{LANDASAN TEORI \\ Kinerja Karyawan}

Kinerja merupakan sebagai fungsi motivasi dan tingkat keberhasilan seseorang. Dalam menyelesaikan pekerjaannya, seseorang harus memiliki tingkat kemauan dan kemampuan tersendiri. Ketersediaan dan keterampilan seseorang tidak cukup efektif untuk mengerjakan pekerjaan tanpa pemahaman yang jelas tentang apa yang akan 
dikerjakan. (Mangkunegara, A. A dan Anwar 2004, 67) menyatakan bahwa kinerja adalah hasil kerja secara kualitas dan kuantitas yang dicapai oleh seorang pegawai dalam melaksanakan tugasnya sesuai dengan tanggung jawab yang diberikan kepadanya.

Pengukuran kinerja adalah suatu proses penilaian kemajuan pekerjaan terhadap tujuan dan sasaran yang telah ditentukan sebelumnya termasuk informasi atas efisiensi penggunaan sumber daya dalam menghasilkan barang/jasa, kualitas barang/jasa, hasil kegiatan dibandingkan dengan maksud yang diinginkan (Robertson, 2006). Sedangkan menurut Robertson dalam Mahsun (2006) menyatakan bahwa pengukuran kinerja adalah suatu proses penilaian kemajuan pekerjaan terhadap tujuan dan sasaran yang telah ditentukan sebelumnya termasuk informasi atas efisiensi penggunaan sumber daya dalam menghasilkan barang/jasa, kualitas barang/jasa, hasil kegiatan dibandingkan dengan maksud yang diinginkan.

Banyak cara dalam mengukur kinerja karyawan, standar pekerjaan dapat ditentukan dari sudut pandang pekerjaan dan digunakan sebagai dasar untuk mengevaluasi setiap pekerjaan. Menurut (Rivai dan Basri 2015) pengukuran didalam kinerja dapat ditentukan atas dasar indikator sebagai berikut:

a. Kuantitas, yaitu jumlah yang harus diselesaikan atau dicapai. Pengukuran kuantitatif melibatkan perhitungan keluaran dari proses atau pelaksanaan kegiatan. Ini berkaitan dengan jumlah yang dihasilkan. Kuantitas kerja adalah jumlah kerja yang dilaksanakan oelh seseorang pegawai dalam suatu periode tertentu, hal ini dapat dilihat dari hasil kerja pegawai dalam kerja, penggunaan waktu tertentu dan kecepatan dalam menyelesaikan tugas dan tanggung jawabnya (Wilson dan Heyel 1987)

b. Kualitas, yaitu mutu yang harus dihasilkan (baik tidaknya), yaitu seberapa baik penyelesaiannya. Ini berkaitan dengan bentuk keluaran. Kualitas kerja adalah mutu seorang karyawan/pegawai dalam hal melaksanakan tugas-tugasnya meliputi kesesuaian, kerapian dan kelengkapan (Wilson dan Heyel 1987)

c. Ketepatan waktu, yaitu sesuai tidaknya dengan waktu yang direncanakan, pengukuran ketetapan waktu merupakan tipe utama dari pengukuran kuantitatif dalam menentukan ketetapan waktu dan penyelesaian kegiatan atau pekerjaan.

\section{Disiplin Kerja}

Secara etimologis, disiplin berasal dari bahasa inggris yaitu "Disciple" yang berarti pengikut atau penganut pengajaran, latihan dan sebaginya. Disiplin lebih tepat diartikan sebagai perilaku yang sesuai dengan peraturan yang berada disuatu perusahaan secara tertulis maupun tidak tertulis. Dalam kenyataannya sangat sulit seluruh peraturan ditaati oleh karyawan. Kedisiplinan adalah kesadaran dan kesediaan seseorang menaati semua peraturan perusahaan dan norma-norma yang berlaku. Kesadaran adalah sikap seseorang yang secara sukarela menaati semua peraturan dan sadar akan tugas dan tanggung jawabnya. Jadi, dia akan mematuhi atau mengerjakan semua tugasnya dengan baik, bukan atas paksaan. Sedangkan yang dimaksud dengan kesediaan adalah suatu sikap, tingkah laku dan perbuatan seseorang yang sesuai dengan peraturan perusahaan, baik yang tertulis maupun tidak (Hasibuan, S.P 2003, 193)

Sedangkan menurut (Handoko, Hani 2000, 208) disiplin adalah kegiatan manajemen untuk menjalankan standar-standar organisasional. Menurut (Sari 2014) mengatakan pada dasarnya banyak indikator yang mempengaruhi tingkat kedisiplinan karyawan suatu organisasi, diataranya adalah: 1) Tujuan dan Kemampuan 2) Teladan 
Pimpinan 3) Balas Jasa 4) Keadilan 5) Waskat 6) Sanksi Hukuman 7) Ketegasan 8) Hubungan Kemanusiaan.

\section{Kepemimpinan}

Isyadi (2004), mendefinisikan beberapa pendapat bahwa kepemimpinan adalah sesuatu yang melekat pada diri pemimpin dan oleh karenanya kepemimpinan itu dikaitkan dengan sifat pembawaan (traits). Berdasarkan definisi tersebut, penentuan atas kepemimpinan seseorang sebenarnya terletak pada bagian peran pengikut memberikan penilaian perilaku dan pemimpin, ketika pemimpin berpengaruh pada pengikutnya. Pemimpin yang efektif harus menghadapi tujuan-tujuan individu, kelompok, dan organisasi. Menurut Stogdill dalam Gibson et al. (1997), Kepemimpinan adalah suatu interaksi antar anggota suatu kelompok. Pemimpin merupakan agen perubahan.

\section{Lingkungan Kerja}

Kehidupan manusia tidak bisa terlepas dari lingkungan. Kenyamanan dalam lingkungan kerja akan berpengaruh terhadap keberhasilan pekerjaan yang dilakukan oleh karyawan. Lingkungan kerja yang kondusif akan dapat memberikan rasa aman dan memungkinkan para karyawan untuk bekerja secara optimal. Lingkungan kerja bisa meliputi sarana dan prasarana yang ada disekitar karyawan seperti tempat kerja, fasilitas kerja, alat bantu pekerjaan, keamanan, kebersihan, pencahayaan, suhu udara, ruang gerak, ketenangan, dan lain-lain. Jika lingkungan kerja yang sehat, nyaman, aman dan menyenangkan bagi karyawan maka dapat dikatakan lingkungan kerja tersebut baik.

Lingkungan kerja adalah segala sesuatu yang ada disekitar karyawan dan dapat mempengaruhi dalam menjalankan tugas yang diembankan kepadanya (Nitisemito dan Nuraini 2013, 19). Menurut (Sedarmayanti 2009, 21) Lingkungan Kerja adalah keseluruhan alat perkakas dan bahan yang dihadapi, lingkungan sekitarnya dimana seseorang bekerja, metode kerjanya, serta pengaturan kerjanya baik sebagai perseorangan maupun kelompok.

\section{Lingkungan Kerja Fisik}

Lingkungan kerja fisik adalah tempat kerja pegawai melakukan aktivitasnya. Lingkungan kerja fisik mempengaruhi semangat dan emosi kerja para karyawan dan faktor-faktor fisik ini mencakup: penerangan, suhu udara, sirkulasi udara, ukuran dan ruang kerja (Sarwono 2005:86). Sedangan menurut Sedarmayanti (2009:22) yang dimaksud lingkungan kerja fisik yaitu semua keadaan berbentuk fisik yang terdapat disekitar tempat kerja dimana dapat mempengaruhi kinerja karyawan baik secara langsung maupun tidak langsung.

Lingkungan kerja fisik dapat dibagi menjadi dua kategori berdasarkan medianya yaitu:

- Lingkungan kerja yang langsung berhubungan dengan karyawan seperti kursi, meja, dan sebagainya.

- Lingkungan perantara atau juga disebut lingkungan kerja yang mempengaruhi kondisi manusia misalnya suhu udara, kelembaban, sirkulasi udara, pencahayaan, kebisingan, getaran mekanik bau-bauan, warna dan lain-lain.

Hubungan antar karyawan dengan lingkungan kerja dalam perusahaan merupakan hal yang tidak dapat dipisahkan, sebab akan menimbulkan tingkat kepuasan kinerja karyawan. Situasi lingkungan dalam menyelesaikan pekerjaan dan interaksi antar karyawan dalam menciptakan kelancaran kerja. 


\section{Lingkungan Kerja Non Fisik}

Menurut Sedarmayati (2009:31) lingkungan kerja non fisik adalah semua keadaan yang terjadi berkaitan dengan hubungan kerja, baik dengan atasan maupun dengan sesama rekan kerja ataupun dengan bawahan. Sedangkan menurut Nitisemito (2000:139) lingkungan kerja non fisik mencerminkan kondisi yang mendukung kerjasama antara tingkat atasan dengan bawahan maupun sesama rekan kerja yang memiliki status jabatan sama di perusahaan.

Dari uraian diatas dapat disimpulkan bahwa lingkungan kerja non fisik merupakan kondisi lingkungan kerja fisik lainnya yang berkaitan dengan hubungan kerja karyawan dan akan mempengaruhi kinerjanya.

\section{METODOLOGI PENELITIAN}

Metode penelitian yang digunakan untuk menjawab rumusan masalah adalah metode survei penjelasan. Metode ini, menghubungkan variabel dan menguji pengaruh. Yang menjadi objek penelitian dalam menyusun jurnal ini adalah PT. Kimia Farma Tbk. Plant Banjaran. Jenis penelitian yang dilakukan adalah puposive sampling dan menggunakan pendekatan kualitiatif, menurut (Sugiyono 2010, 218) yaitu ; "Purposive sampling adalah teknik pengambilan sample sumber data dengan pertimbangan tertentu.

Populasi merupakan keseluruhan unsur yang memiliki ciri dan karakteristik yang sama. Popuulasi adalh jumlah objek (satuan-satuan atau individu-individu) yang karakteristiknya hendak diduga (J. Supranto 2008, 18) Dalam penelitian ini yang menjadi populasi adalah jumlah keseluruhan karyawan PT. Kimia Farma, Tbk.

Sampel merupakan sebagian dari jumah populasi yang diambil untuk diteliti dan karakteristiknya hendak diduga (J. Supranto 2008, 18). Yang menjadi sampel pada penelitian ini adalah pada PT. Kimia Farma, Tbk. Memiliki beberapa bagian produksi, maka dari itu penulis mengambil sampel karyawan pada Bagian Produksi Granulasi 1 PT. Kimia Farma, Tbk.

Dalam melakukan penelitian ini, penulis memerlukan beberapa data dan informasi yang jelas, lengkap dan akurat. Adapun sumber data yang penulis gunakan dalam penelitian ini yaitu data primer. Data Primer merupakan data yang diperoleh langsung dari lokasi penelitian atau sumber data pertama dari objek penelitian dan sumber data atau narasumber pada penelitian ini adalah pimpinan serta staff yang dijadikan sebagai sampel. Data primer berisi mengenai pernyataan atau pertanyaan yang disertai dengan usia, status, jenis kelamin, masa kerja, tingkat pendidikan, posisi jabatan dan mengenai disiplin kerja, kinerja karyawan dan pemberian motivasi kepada karyawan.

Pemilihan teknik pengumpulan data dalam penelitian ini berdasarkan permasalahan yang diteliti. Maka penulis menggunakan metode pegumpulan data berupa wawancara. Wawancara yang dilakukan yaitu penulis mengajukan beberapa pertanyaan langsung kepada informan yang dapat memberikan informasi yang jelas dan sesuai dengan masalah yang akan diteliti. Informan tersebut merupakan pimpinan Bagian Produksi Granulasi 1 PT. Kimia Farma, Tbk. Plant Banjaran.

\section{HASIL PENELITIAN}

\section{Pengaruh Kondisi Kerja Terhadap Motivasi Kerja}

Kondisi kerja berdampak pada motivasi kerja, melalui intruksi yang baik akan memberikan dampak positif. Artinya apabila kondisi lingkungan kerja yang sehat serta didukung dengan keselamatan lingkungan, jam kerja yang sehat, tata letak alat kerja yang rapih, fasilitas kerja dan suasana kerja yang nyaman dapat meningkatkan motivasi kerja 
karyawan. Melalui motivasi karyawan yang meningkat, maka akan tercipatanya lingkungan kerja yang sehat karena karyawan memiliki peran yang penting dalam sebuah organisasi. Kondisi kerja yang baik sangat membantu karyawan untuk berkonsentrasi dalam menyelesaikan tugas yang diberikan.

Berdasarkan hasil wawancara yang kami lakukan terhadap supervisor dan beberapa pegawai bagian produksi granulasi 1 PT. Kimia Farma, Tbk. diperoleh hasil bahwa motivasi kinerja karyawan meningkat dikarenakan pihak organisasi memfasilitasi karyawan berupa alat pelindung diri yang lengkap, sehingga dapat mengurangi kecelakaan kerja.

\section{Pengaruh Motivasi Kerja terhadap Kinerja SDM}

Motivasi kerja mempunyai pengaruh yang signifikan terhadap kinerja SDM, dengan arah positif. (Muhamadun 2012)

Berdasarkan hasil wawancara terhadap supervisor daa beberapa pegawai bagian produksi granulasi 1 PT. Kimia Farma, Tbk. diperoleh hasil bahwa organisasi menyadari akan pentingnya memberikan apresiasi terhadap kinerja karyawan serta melakukan evaluasi kinerja secara berkala maka dari itu pihak organisasi melakukan kegiatan rewarding dan upgrading dengan upaya dapat meningkatkan dan mengembalikan semangat kerja karyawan. Disamping itu, organisasi juga melakukan kegiatan diluar pekerjaan guna untuk menjalin hubungan silaturahmi yang lebih erat.

\section{Pengaruh Disiplin Kerja terhadap Kinerja Karyawan}

Berdasarkan hasil wawancara mengenai kedisiplinan kerja pihak organisasi belum melakukan tindakan tegas mengenai Prosedur Operasi Standar (SOP) yang berlaku. Pihak organisasi hanya menyarankan kepada karyawannya untuk menyadari dampak buruk dari bahan kimia jika karyawan tidak mematuhi Prosedur Operasi Standar (SOP) dan Alat Pelindung Diri (APD) yang telah ditentukan.

\section{Pengaruh Motivasi Kerja dan Disiplin Kerja terhadap Kinerja Karyawan}

Dalam hal ini motivasi kerja dan kedisiplinan kerja memiliki hubungan yang kuat terhadap kinerja karyawan. Sebagai contoh karyawan yang tidak memiliki motivasi kerja dan tingkat kedisiplinan yang kurang dapat menghasilkan kinerja yang kurang baik serta memberikan dampak yang negatif bagi keberlangsungan organisasi. Jika motivasi kerja baik namun kedisiplinan buruk maka tidak akan memberikan dampak yang positif begitu pula jika motivasi kerja buruk dan kedisiplian baik tidak dapat memberikan dampak yang positif. Namun berbeda bila karyawan yang memiliki motivasi kerja yang tinggi serta akan sadar pada kedisiplinan maka akan memberikan kontribusi kinerja yang berdampak positif bagi organisasi. Karena dua hal tersebut sangat berhubungan erat semakin tinggi motivasi kerja dan disiplin kerja maka akan mencapai target dari suatu organisasi.

Berdasarkan hasil wawancara dengan supervisor Bagian Produksi Granulasi 1 PT. Kimia Farma, Tbk. dapat disimpulkan bahwa jika motivasi kerja dan kedisiplinan kerja karyawan yang tinggi maka akan mencapai target produksi yaitu dalam satu minggu menghasilkan 25 batch. Bagian Produksi Granulasi merupakan tahap awal sebelum diolah menjadi tablet. Jadi, dalam proses granulasi ini masih belum bisa terlihat jumlah hasil tabletnya karena masih berupa bahan produksi dalam satuan kilogram.

\section{KESIMPULAN}

Berdasarkan permasalahan dalam penelitian ini adalah Bagaimana pengaruh gaya kepemimpinan dalam pemberian motivasi dan disiplin kerja terhadap kinerja karyawan (Studi Kasus Pada Bagian Produksi Granulasi 1 PT. Kimia Farma, Tbk.) dapat disimpulkan jika kondisi kerja karyawan semakin baik maka kinerja karyawan akan 
meningkat. Artinya peningkatan kinerja karyawan tergantung pada indikator kondisi kerja yaitu keselamatan lingkungan, jam kerja, tata letak yang nyaman, fasilitas kerja dan suasana kerja yang nyaman. Jika motivasi kerja karyawan semakin baik, maka kinerja karyawan akan meningkat. Artinya peningkatan kinerja karyawan didasarkan pada beberapa indikator motivasi kerja yang meliputi ketulusan suatu karyawan, hasil kerja yang dihargai dan pemberian suatu penghargaan bagi karyawan yang berprestasi. Keberhasilan Bagian Produksi Granulasi 1 PT. Kimia Farma, Tbk. dalam mencapai target produksi sangat bergantung pada kualitas kinerja karyawan yang baik, maka dari itu peningkatan motivasi dan kedisiplinan sangat diperhatikan oleh organisasi.

\section{DAFTAR PUSTAKA}

Handoko, Hani, T. 2000. Manajemen Sumber Daya Manusia. Keempat. Yogyakarta: BPFE UGM.

Hasibuan, S.P, Malayu. 2003. Manajemen Sumber Daya Manusia. Revisi. Jakarta: Bumi Aksara.

J. Supranto. 2008. Statistika Teori Dan Aplikasi. Ketujuh. Jakarta: Erlangga.

Mangkunegara, A. A dan Anwar, P. 2004. Manajemen Sumber Daya Perusahaan. Bandung: Remaja Rosdakarya.

Muhamadun, Nunung Ghoniyah. 2012. "Peningkatan Kinerja Sdm Melalui Kondisi Kerja, Konten Pekerjaan Dan Pengembangan Karir Dengan Mediasi Motivasi Kerja." Jurnal Bisnis dan Ekonomi (JBE) 19(2): 142-52.

Nitisemito dan Nuraini. 2013. Manajemen Sumber Daya Manusia. Pekanbaru: Yayasan Aini Syam.

Rivai dan Basri. 2015. "Pengaruh Pemberian Motivasi Dan Disiplin Kerja Terhadap Kinerja Karyawan Pada Karyawan Tetap PT.LG Electronics Indonesia Kantor Cabang Pekanbaru." Jom Fisip Vol.4(2): 2.

Sari, yanti. 2014. "PENGARUH KEPEMIMPINAN, MOTIVASI DAN DISIPLIN KERJA TERHADAP KINERJA KARYAWAN PADA PT. PATRA KOMALA DI DUMAI Yanti Komala Sari 1) 1)." VI(2): 119-27.

Sedarmayanti. 2009. Sumber Daya Manusia Dan Produktivitas Kerja. Bandung: CV Mandar Maju.

Sugiyono. 2010. Metodologi Penelitian Pendidikan, Pendekatan Kuantitatif, Kualitatif, Dan R\&D. Bandung: Alfabeta.

Wilson dan Heyel. 1987. Hand Book Modern Office Management and Administration Service. New Jersey: Mc Graw Hill Inc. 